\title{
THE ROLE OF HIF-1 $\alpha$ IN REGIONAL LYMPH NODES METASTASIS IN COLORECTAL ADENOCARCINOMA
}

\author{
Ladyna Rumapar, Sjahjenny Mustokoweni, Alphania Rahniayu \\ Department of Anatomic Pathology, Faculty of Medicine, Universitas Airlangga, Dr. Soetomo Hospital, Surabaya
}

\begin{abstract}
ABSTRAK
Karsinoma kolorektal memiliki angka morbiditas dan mortalitas yang tinggi di seluruh dunia, dengan >90\% merupakan adenokarsinoma. Karsinoma kolorektal merupakan salah satu kanker yang paling sering bermetastasis, terutama ke kelenjar getah bening. Angiogenesis memiliki peranan penting dalam pertumbuhan tumor dan metastasis. Hipoksia merupakan faktor pemicu yang memicu terjadinya angiogenesis. Hypoxia induced factor- 1 (HIF-1) telah diidentifikasi sebagai protein yang penting dan bereaksi langsung terhadap hipoksia. HIF-1 $\alpha$, salah satu subunit dari HIF-1, merupakan regulator penting dalam angiogenesis. Dilakukan analisis ekspresi HIF-1 $\alpha$ pada adenokarsinoma kolorektal, dengan dan tanpa metastasis ke KGB regional, untuk mengungkap peranan protein tersebut dalam proses metastasis. Penelitian ini bertujuan untuk membuktikan adanya peran HIF-1 $\alpha$ pada proses metastasis KGB regional adenokarsinoma kolorektal. Penelitian observasional analitik dilakukan pada 30 sampel blok parafin adenokarsinoma kolorektal dengan dan tanpa metastasis pada KGB regional di Laboratorium Patologi Anatomi RSUD Dr. Soetomo, Surabaya. Deteksi ekspresi HIF-1 $\alpha$ dilakukan dengan pengecatan imunohistokimia menggunakan antibodi HIF-1 $\alpha$. Hasil penelitian dianalisis secara statistik menggunakan uji statistik Mann-Whitney dan Kruskal- Wallis. Pada penelitian ini tidak didapatkan perbedaan ekspresi HIF-1 $\alpha$ antara adenokarsinoma kolorektal dengan metastasis KGB dan tanpa metastasis KGB ( $p>0$,05). Sebagai simpulan, HIF-1 $\alpha$ tidak berperan dalam metastasis KGB pada adenokarsinoma kolorektal. (FMI 2018;54:1-5)
\end{abstract}

Kata kunci: Adenokarsinoma kolorektal; HIF-1 $\alpha$; KGB regional

\begin{abstract}
Colorectal carcinoma has high morbidity and mortality rate worldwide, in which over 90\% are adenocarcinoma. Colorectal carcinoma is one of the most cancer that metastasize to the lymph node. Angiogenesis have an important role in tumor growth and metastasis. Hypoxia is the trigger factor for angiogenesis. Hypoxia induced factor- 1 (HIF-1) is one critical protein directly reacting to hypoxia. HIF-1 $\alpha$, a HIF-1 subunit, is an important regulator of angiogenesis. This study analyzed HIF-1 $\alpha$ expression in colorectal adenocarcinoma with and without regional lymph node metastasis. This study was to prove that HIF-1 $\alpha$ has a role in regional lymph node metastasis in colorectal adenocarcinoma. An analytical observational study was conducted on thirty formalin fixed paraffinembedded colorectal adenocarcinoma tissues from Anatomic Pathology Laboratory of Dr. Soetomo Hospital. Detection of HIF-1 $\alpha$ expressions were performed with immunohistochemistry method, using HIF-1 $\alpha$ antibody. It were statistically analyzed using MannWhitney and Kruskal- Wallis methods. There were no significant differences in the expression of HIF-1 $\alpha$ in colorectal adenocarcinoma with or without lymph node (LN) metastasis ( $p>0.05)$. As a conclusion, this study showed that HIF-1 $\alpha$ has no role in LN metastasis in colorectal adenocarcinoma. (FMI 2018;54:1-5)
\end{abstract}

Keywords: Colorectal adenocarcinoma; HIF-1 $\alpha$; regional LN

Correspondence: Alphania Rahniayu, Department of Anatomic Pathology, Faculty of Medicine, Universitas Airlangga, Surabaya. Phone: +6281234168612. Email: azkamom@gmail.com

\section{INTRODUCTION}

Colorectal carcinoma (CRC) has high rate of morbidity and mortality worldwide, both in males and females. Over $90 \%$ of the CRC is of adenocarcinoma type. CRC is one of the most commonly metastatic cancers, especially to the lymph nodes (LN), liver, and the peritoneum. Adjuvant therapy, such as chemotherapy and radiotherapy, have been widely applied, but late-stage CRC is still difficult to treat. It is therefore necessary to evaluate whether some proteins associated with metastasis can be used as a marker for metastasis in the CRC
(Cao et al 2009, Bosman et al 2010, Wu et al 2010). Rapid proliferation of tumors can lead to hypoxia in the microenvironment. Hypoxia is a triggering factor that induces angiogenesis. Angiogenesis has an important role in tumor growth and metastasis (Cao et al 2009). HIF-1 has been identified as an important protein and reacts directly to hypoxia. HIF-1 $\alpha$ is one subunit of HIF-1. HIF-1 $\alpha$ is important regulator in angiogenesis. (George et al 2001, Nathanson 2003).

The correlation between HIF- $1 \alpha$ expression with regional LN status was reported in colorectal adenocarci- 
noma, but there were also studies that reported no correlation between HIF-1 $\alpha$ expression with the regional $\mathrm{LN}$ status of colorectal adenocarcinoma. There is not much information about the cellular and molecular mechanisms involved in this lymphatic metastasis (Cao et al 2009, Wu et al 2010, Kwon et al 2010). This study aimed to prove the role of HIF- $1 \alpha$ and VEGF in metastasis to regional LN.

\section{MATERIALS AND METHODS}

The research design used was analytic observational with cross sectional approach. The study population were all blocks of paraffin of colorectal adenocarcinoma cases in Anatomic Pathology Laboratory of Dr. Soetomo Hospital, Surabaya, during the period of July 1, 2015 to June 30, 2016. In this period, there were 84 cases of colorectal adenocarcinoma. The samples for the study were taken by random sampling, divided into 15 samples in each group with and without regional LN metastasis. Inclusion criteria were paraffin blocks of surgical specimens, with a minimum amount of 12 regional LN, still having representative tumor cells for immunohistochemical examination, and histopathologic examination results that revealed colorectal adenocarcinoma profile. The diagnosis was established by anatomic pathologist at the Department of Anatomic Pathology, Dr. Soetomo Hospital, Surabaya.

The expression of HIF-1 $\alpha$ was immuno-histochemically examined with monoclonal rabbit antibody HIF-1 $\alpha$ (Biocare) with 1:50 dilution. The expression of HIF-1 $\alpha$ is said to be positive if it is in the cytoplasm. Positive tumor cells were calculated visually with a binocular light microscope, then evaluated on the intensity and percentage of HIF- $1 \alpha$ positively stained cells. The collected data were analyzed statistically. Differences of HIF-1 $\alpha$ expression were analyzed by Mann-Whitney test $(\mathrm{a}<0.05)$.

\section{RESULTS}

Mean age data of the patient in this study was $56.37 \pm$ 10.36. The youngest patient aged 32 years and the oldest was 80 years. Age grouping was conducted into 5 groups with span of 10 years. The ages of colorectal adenocarcinoma patients were in the range of 51-60 years in as much as $40 \%$. Sex data showed balanced proportion of males and females, with $50 \%$ of males and $50 \%$ of females. The location of the tumor was mostly in the colon, as much as $50 \%$ of the cases, and the least was in the caecum, as much as $6.67 \%$ of the cases. Most of the tumor had high degree of differentiation $(83.33 \%$ of cases), while those with poor differentiation was only $3.33 \%$ of cases. The depth of tumor invasion in this study was mostly T3, as much as 23 (76.67\%) cases. Mann-Whitney and Kruskal- Wallis tests showed that there was no statistically significant difference in HIF$1 \alpha$ expression between different age groups, sex, tumor location, degree of differentiation, and depth of invasion, both in colorectal adenocarcinoma with and without regional LN metastasis $(\mathrm{p}>0,05)$ (Table 1-5).

In this study, HIF-1 $\alpha$ expression was calculated in each group of samples based on the intensity and percentage of positively stained cells. We found median 3 in groups with and without metastasis, for intensity score and cell count as well as the score from multiplication of intensity and cell count (Fig. $1 \&$ Table 6). The expression of HIF- $1 \alpha$ is shown in Fig. 2.

Mann-Whitney statistical analysis showed no difference in HIF- $1 \alpha$ expression between colorectal adenocarcinoma with and without LN metastasis $(p>0.05)$, either on the intensity of expression, the number of cells expressing HIF-1 $\alpha$, or the combined scores of intensity and number of cells expressing HIF-1 $\alpha$. There was no increase in HIF- $1 \alpha$ expression in colorectal adenocarcinoma with LN metastasis ( $>>0.05$ ) (Table 1).

Table 1 . HIF 1- $\alpha$ expression by age category

\begin{tabular}{ccccc}
\hline \multirow{2}{*}{ Variable } & Category & \multicolumn{2}{c}{ LN metastasis } & Total \\
\cline { 3 - 4 } & $\leq 40$ years & $2.5 \pm-(2-3)$ & - & \\
\hline \multirow{6}{*}{ Age group } & 41-50 years & $3.0 \pm-(3-3)$ & $2.5 \pm 0.5(2-3)$ & $3.0 \pm 0.5(2-3)$ \\
& $51-60$ years & $3.0 \pm 1.0(0-3)$ & $3.0 \pm 0.5(2-3)$ & $3.0 \pm 0.5(0-3)$ \\
& 61-70 years & $2.0 \pm 0.5(1-3)$ & $2.5 \pm-(2-3)$ & $2.0 \pm 0.5(1-3)$ \\
& $>70$ years & $2.5 \pm-(2-3)$ & $1.0 \pm-(1-1)$ & $2.0 \pm-(1-3)$ \\
\cline { 2 - 4 } & $\mathrm{P}$ & 0.504 & 0.321 & 0.472 \\
\hline
\end{tabular}


Table 2. HIF 1- $\alpha$ expression by sex category

\begin{tabular}{ccccc}
\hline Variable & Category & \multicolumn{2}{c}{ LN metastasis } & \multirow{2}{*}{ Total } \\
\cline { 3 - 4 } & & \multicolumn{2}{c}{+} & \\
\hline \multirow{2}{*}{$\begin{array}{c}\text { Sex } \\
\text { category }\end{array}$} & Male & $2.5 \pm 0.5(0-3)$ & $3.0 \pm 0.5(2-3)$ & $3.0 \pm 0.5(0-3)$ \\
\cline { 2 - 5 } & Female & $3.0 \pm 0.5(2-3)$ & $2.0 \pm 0.5(1-3)$ & $2.0 \pm 0.5(1-3)$ \\
\cline { 2 - 5 } & $\mathrm{p}$ & 0.798 & 0.171 & 0.458 \\
\hline
\end{tabular}

Table 3. HIF 1- $\alpha$ expression by tumor location category

\begin{tabular}{|c|c|c|c|c|c|}
\hline \multirow{2}{*}{ Variable } & \multirow{2}{*}{ Category } & \multicolumn{2}{|c|}{$\mathrm{LN}$ metastasis } & \multirow{2}{*}{\multicolumn{2}{|c|}{ Total }} \\
\hline & & + & - & & \\
\hline \multirow{5}{*}{ Location } & Colon & $2.5 \pm 1.0(0-3)$ & $2.0 \pm 0.5(2-3)$ & $2.0 \pm$ & $0.5(0-3)$ \\
\hline & Rectum & $3.0 \pm-(2-3)$ & $3.0 \pm 1.0(1-3)$ & $3.0 \pm$ & $0.5(1-3)$ \\
\hline & Caecum & - & $2.5 \pm-(2-3)$ & $2.5 \pm$ & $-(2-3)$ \\
\hline & Rectosigmoid & $2.5 \pm 0.5(2-3)$ & $3.0 \pm-(3-3)$ & $3.0 \pm$ & $0.5(2-3)$ \\
\hline & $\mathrm{p}$ & 0.765 & 0.828 & & 0.873 \\
\hline
\end{tabular}

Table 4. HIF 1- $\alpha$ expression by degree of differentiation category

\begin{tabular}{|c|c|c|c|c|}
\hline \multirow{2}{*}{ Variable } & \multirow{2}{*}{ Category } & \multicolumn{2}{|c|}{ LN metastasis } & \multirow[t]{2}{*}{ Total } \\
\hline & & + & - & \\
\hline \multirow{4}{*}{ Differentiation } & Well & $2.5 \pm 0.5(2-3)$ & $3.0 \pm 0.5(1-3)$ & $3.0 \pm 0.5(1-3)$ \\
\hline & Moderate & $3.0 \pm 1.0(1-3)$ & - & $3.0 \pm 1.0(1-3)$ \\
\hline & Poorly & $0.0 \pm-(0-0)$ & - & $0.0 \pm-(0-0)$ \\
\hline & $\mathrm{p}$ & 0.187 & - & 0.159 \\
\hline
\end{tabular}

Table 5. HIF 1- $\alpha$ expression by depth of invasion category (T stage)

\begin{tabular}{lcccc}
\hline \multirow{2}{*}{ Variable } & Category & \multicolumn{2}{c}{ LN metastasis } & Total \\
\cline { 3 - 5 } & 1 & - & $1.0 \pm-(1-1)$ & $1.0 \pm-(1-1)$ \\
& 2 & $2.0 \pm-(2-3)$ & $2.5 \pm-(2-3)$ & $2.0 \pm 0.5(2-3)$ \\
\multirow{3}{*}{ T Stage } & 3 & $3.0 \pm 0.5(0-3)$ & $3.0 \pm 0.5(2-3)$ & $3.0 \pm 0.5(0-3)$ \\
& 4 & $2.0 \pm-(2-2)$ & - & $2.0 \pm-(2-2)$ \\
\cline { 2 - 5 } & $\mathrm{p}$ & 0.654 & 0.185 & 0.267 \\
\hline
\end{tabular}




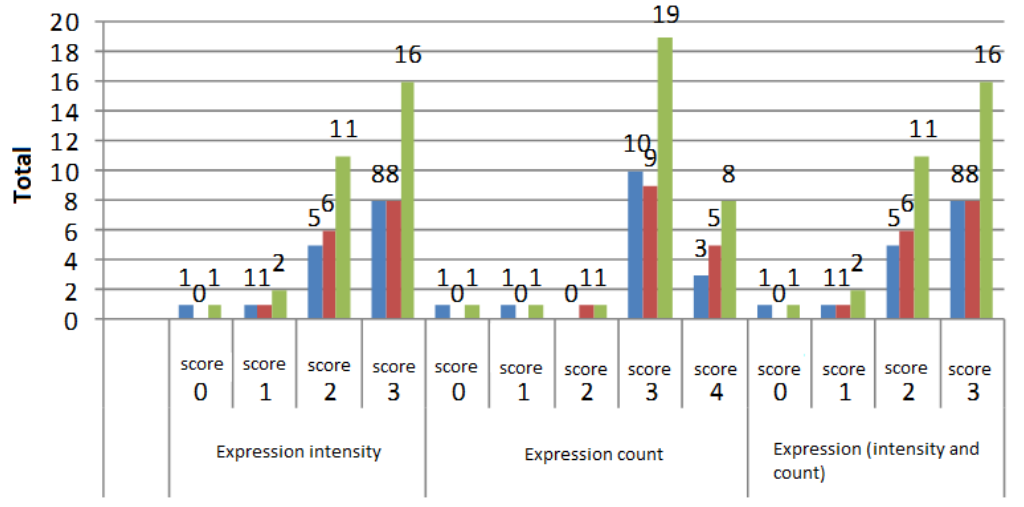

HIF-1 $\alpha$ expression

With metastatis

Without metastatis Total

Fig. 1. Distribution of HIF-1 $\alpha$ expression in colorectal adenocarcinoma with and without LN metastasis.

Table 6. HIF-1 $\alpha$ expression based on metastatic status

\begin{tabular}{lcccccc}
\hline $\begin{array}{c}\text { HIF-1 } \alpha \\
\text { expression }\end{array}$ & Metastasis & Median & $\begin{array}{c}\text { Interquartile } \\
\text { deviation }\end{array}$ & Min & Max & $\mathrm{p}$ \\
\hline Intensity & + & 3 & 0.5 & 0 & 3 & \multirow{2}{*}{0.853} \\
\hline \multirow{2}{*}{ Count } & - & 3 & 0.5 & 1 & 3 & \multirow{2}{*}{0.331} \\
\hline Intensity \& & + & 3 & 0 & 0 & 4 & \multirow{2}{*}{0.853} \\
count & - & 3 & 0.5 & 2 & 4 & 3 \\
\hline
\end{tabular}
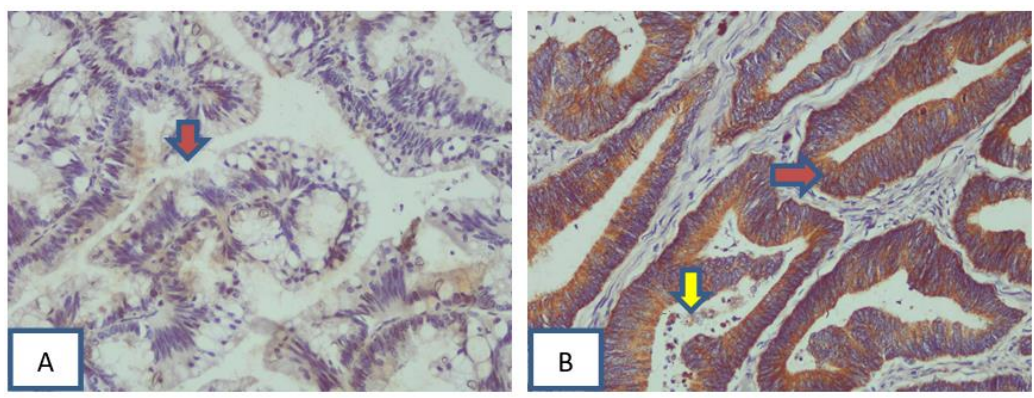

Fig. 2. Expression of HIF-1 $\alpha$ A. Tumor cells stained with HIF-1 $\alpha$ antibody in the cytoplasm, with an intensity score of $1+$ (red arrow) (IHC, 400x). B. Tumor cells stained with HIF-1 $\alpha$ antibody in the cytoplasm, with an intensity score of $3+$ (red arrow). Neutrophils also appear in this antibody (yellow arrow) (IHC, 400x).

\section{DISCUSSION}

Colorectal carcinoma is one of the most common cancers in the world, ranked fourth in males, after lung, prostate, and gastric carcinoma; and ranked third in women, after breast and cervical cancer. The histologic type of adenocarcinoma was studied in this study because more than $90 \%$ of colorectal carcinomas were adenocarcinomas. Its association with regional LN status was studied because metastasis in LN had an independent prognostic interest for colorectal carcinoma
(Hamilton \& Aaltonen 2000, Shepherd et al 2013). Colorectal adenocarcinoma patients mostly have an age range of 51-60 years. This is consistent with a previous study suggesting that the incidence of colorectal carcinoma increases with age, and rarely before age 40 (Hamilton \& Aaltonen 2000). In this study, we found balanced proportion of males and females, each of them was 15 . This is in accordance with another study that adenocarcinoma in colorectal cancer can be found in both sexes (Shepherd et al 2013). Most prevalent location of the tumor is in the colon and the rectum. The 
results of this study are in accordance with that of Cao et al (2009) who found that the location of tumors in populations with high incidence rates is more common in the colon and the rectum than in other sites. The dominant tumor depth of invasion ( $\mathrm{T}$ stage) was $\mathrm{T} 3$, which is in accordance with previous study conducted by Kwon et al (2010).

In this study we also assessed the HIF-1 $\alpha$ expression on several clinicopathologuc parameters like age, sex, tumor location, differentiation grade, and the depth of invasion ( $\mathrm{T}$ stage). The result showed that in all of those clinicopathologic parameters, there were no differences in HIF-1 $\alpha$ expression, whether in group with or without lymph nodes metastasis, and also in overall group $(p>0,05)$. In the matter of age group, this study is in accordance to the study by Cao et al (2009), Kwon et al (2010), Decastel et al (2014), Wincewicz et al (2007), and $\mathrm{Wu}$ et al (2010), who also found that there was no correlation between HIF-1 $\alpha$ expression and patient age group p>0,05) (Cao et al 2009, Kwon et al 2010 Decastel et al 2014, Wincewicz et al 2007, and Wu et al 2010).

Mann-Whitney statistical results showed that there was no difference in HIF-1 $\alpha$ expression between colorectal adenocarcinoma with and without LN metastasis ( $p>$ 0.05). This is in accordance with a study conducted by Kwon et al (2010) who found no significant correlation between HIF-1 expression and clinicopathologic parameter, one of the LN metastasis parameters. This may be due to the complicated correlation between HIF-1 $\alpha$ and mutations which occur in the suppressor gene tumor, one of which is p53. One of the HIF-1 $\alpha$ regulatory mechanisms is the Mdm pathway, in which HIF$1 \alpha$ binds to p53, and ubiquination is taking place mediated by Mdm2 (mouse double minute 2 homologue), resulting in $\mathrm{HIF}-1 \alpha$ degradation by $\mathrm{Mdm} 2$ (Kwon et al 2010, Powis \& Kirkpatrick 2004, Masoud \& Li 2015).

\section{CONCLUSION}

In colorectal adenocarcinoma, HIF- $1 \alpha$ do not play a role in LN metastasis. Thus, it cannot serve as a marker of metastasis in this cancer.

\section{REFERENCES}

Bosman FT, Carneiro F, Hruban R.H, Theise N.D (2010). Carcinoma of the colon and rectum. World Health Organization Classification of Tumours of the Digestive System. Lyon, IARC, 134-138

Cao D, Hou M, Guan Y, Jiang M, Yang Y, Gou H (2009). Expression of HIF-1 $\alpha$ and VEGF in colorectal cancer: association with clinical outcomes and prognostics implications. BMC Cancer 9, 432

Decastel M, Andrea AM, Lubeth M (2014). Inflammatory and cell adhesion protein markers in colorectal cancer in patient seen at the teaching hospital of Guadalupe: Role of NF kappaB and Pselectin. J Cytol Histol 5, 276

George ML, Tutton MG, Janssen F (2001). VEGF-A, VEGF-C and VEGF-C in colorectal cancer progression. Nature publishing group, 420-427

Hamilton SR, Aaltonen LA (2000). Pathology and Genetics of tumor of the Digestive System. Lyon, IARC Press, p 103-119

Kwon HC, Kim SH, Oh SY (2010). Clinicopathological significance of nuclear factor-kappa B, HIF-1 $\alpha$, and vascular endothelial growth factor expression in stage III colorectal cancer. Japanese cancer association 101, 1557-1561

Masoud GN, Li W (2015). HIF-1 $\alpha$ pahway: role, regulation and intervension for cancer therapy. Acta Pharmaceutica Sinica B

Nathanson SD (2003). Insights into the mechanism of lymph node metastasis. American Cancer Society, 413-423.

Powis G, Kirkpatrick L (2004). Hypoxia inducible factor-1a as a cancer drug target. Molecular Cancer Therapeutics, p.647-654

Shepherd NA, Warren BE, Williams GT (2013). Morson and Dawson's Gastrointestinal Pathology, 5th ed.. New Jersey, Blackwell Publishing Ltd., p 685-715

Wincewicz A, Sulkowska M, Koda M (2007). Clinicopathological Significance and Linkage of the Distribution of HIF-1 $\alpha$ and GLUT-1 in Human Primary Colorectal Cancer. Pathology Oncology Research vol 13, no.1, 15-20

Wu Y, Jin M, Xu Z (2010). Clinicopathologic Significance of HIF-1 $\alpha$, CXCR4, and VEGF Expression in Colon Cancer. Hindawi Publishing Corporation, p 110 